ISSN 2442-3041

Math Didactic: Jurnal Pendidikan Matematika

Vol. 1, No.1, Januari - April 2015

(C) STKIP PGRI Banjarmasin

\title{
PEMBINAAN KARAKTER DALAM PEMBELAJARAN MATEMATIKA ${ }^{2}$
}

\author{
Agung Hartoyo \\ Jurusan Pendidikan MIPA FKIP Universitas Tanjung Pura, Pontianak \\ E-mail: ag_hartoyo@yahoo.com
}

\begin{abstract}
Abstrak: Anak-anak adalah harta karun bangsa. Nasib masa depan bangsa ada di pundak para generasi muda. Memperlakukan anak secara istimewa, baik perkembangan emosional, kesehatan, kecerdasan maupun perilaku mereka menjadi kewajiban bersama. Para pendidik bertanggung jawab untuk menggelorakan revolusi mental dalam rangka mengembangkan kemampuan dan membentuk watak serta peradaban bangsa yang bermartabat dalam mencerdaskan kehidupan bangsa. Intergrasi pendidikan karakter dalam pembelajaran pada setiap mata pelajaran diarahkan untuk membawa peserta didik ke pengenalan nilai-nilai secara kognitif, penghayatan nilai secara afektif, dan bermuara pada pengamalan nilai secara nyata. Pendidikan karakter membekali kepada peserta didik ilmu, pengetahuan dan pengalaman budaya, perilaku yang berorientasi pada nilai-nilai ideal kehidupan, baik yang bersumber pada budaya lokal maupun budaya luar. Ada banyak local genius khasanah budaya bangsa yang dapat digali dari seantero kawasan nusantara yang sarat makna dan kaya akan nilai-nilai luhur budaya bangsa. Potensi budaya dikembangkan sebagai basis dan sumber belajar berbagai mata pelajaran untuk mewujudkan bangsa yang berjati diri. Matematika bukan sekedar kegiatan hitung menghitung, tetapi banyak yang berkaitan dengan pemberdayaan berbagai kekayaan yang tersedia di sekitar kehidupan peserta didik. Para guru matematika meski berpikir, berkreasi dan menghasilkan karya yang berguna untuk pembelajaran matematika, agar dapat mengajar dan mendidik peserta didik menuju masa depannya sebagaimana dicita-citakan dalam tujuan pendidikan nasional.
\end{abstract}

Kata kunci: pendidikan karakter, pembelajaran matematika, kreativitas.

Dalam buku yang diberi judul Education for Character, How Our Schools Can Teach Respect and Responsibility, Lickona (1991) memulai tulisannya dengan pertanyaan, "Apakah sekolah seharusnya memberikan pendidikan tentang nilai-nilai?". Pertanyaan tersebut telah menjadi perdebatan pada beberapa dekade silam hingga kini. Satu pihak mengatakan bahwa pendidikan nilai seharusnya diajarkan kepada anak-anak, pihak lain memperdebatkan "nilai-nilai moral mana" yang seharusnya diajarkan. Pendidikan moral bukanlah sebuah topik baru dalam pendidikan. Pendidikan moral sudah seumur pendidikan itu sendiri. Sepanjang sejarah berlangsungnya pendidikan, pada dasarnya pendidikan memiliki tujuan untuk membimbing para generasi muda untuk

\footnotetext{
${ }^{2}$ Disampaikan pada Seminar Nasional Pendidikan Matematika STKIP PGRI Banjarmasin, 28 Januari 2015
} 
menjadi cerdas dan memiliki perilaku berbudi.

Sejak pemberlakuan Kurikulum 2006 di sekolah di Indonesia, pendidikan kita kembali hangat membicarakan tentang penerapan pendidikan moral, pendidikan nilai atau pendidikan karakter dalam pembelajaran di kelas. Perbuatan baik, menjunjung tinggi keadilan, menjaga kesusilaan, berperilaku bijaksana dan bertindak jujur sebagai nilainilai yang harus dipegang teguh oleh manusia, menjadi bahan pemikiran untuk dibelajarkan kepada peserta didik. Sebagai anggota masyarakat dari suatu bangsa, dalam menjalani hidup dan kehidupannya, manusia terikat oleh peraturan-peraturan yang dibuat untuk mengatur hubungannya dengan sesama, maupun peraturan Sang Pencipta dalam hubungannya dengan Yangmahakuasa. Apabila dalam menjalani kehidupan berjalan sesuai dengan hukum yang berlaku, ia berada pada arah yang benar, sehingga segala sesuatunya menjadi tenang, damai, indah, teratur, subur dan makmur. Bumi dan alampun dengan segala isinya juga akan berjalan sesuai dengan hukum materi - hukum alam - atau ketetapan Sang Pencipta. Inilah harapan yang ingin dicapai dari pembelajaran yang mengintegrasikan pendidikan karakter.

Namun, dalam praktek kehidupan sering didengar atau diketahui dari berbagai media sosial tentang masalah-masalah pelanggaran aturan dan norma-norma yang dilakukan oleh berbagai kalangan, baik anakanak maupun orang tua. Anak-anak muda yang hidup dengan rendahnya kesadaran moral kini muncul dengan berbagai modus, seperti merokok, minum-minuman keras dan obat terlarang, kekerasan fisik dan seksual, vandalisme, penghinaan dan perampasan hakhak orang lain, mengabaikan kebersihan dan kesehatan lingkungan sekolah, pemborosan sumber-sumber daya dan lain sebagainya. Hal yang sama juga banyak dilakukan oleh orangorang tua. Padahal dalam ketentuan agama dikemukakan bahwa orang yang melakukan perbuatan menyimpang dan berjalan ke arah berlawanan dengan hukum yang berlaku, ia akan mendapatkan balasan yang setimpal. Fakta-fakta perusakan lingkungan yang dilakukan oleh sekelompok masyarakat membuahkan kesengsaraan bagi pelakunya dalam waktu yang tidak lama. Banjir terdengar di berbagai penjuru tanah air meskipun hujan baru saja dimulai dan masih awal musim hujan. Di saat musim kemarau banyak daerah yang kekurangan air sebagai akibat menipisnya kantong-kantong penahan dan resapan air. Dalam bertindak tidak berpegang teguh dan kurang bijak memperlakukan aturan-aturan, baik dalam hubungannya dengan sesama, dengan Tuhan, dan dengan lingkungan alam. Manusia mengalami kemunduran mental dan tata nilai.

Tentu saja tidak semua anak muda melakukan tindakan yang menyimpang dari standar moral; sehingga banyak juga sikap anak-anak muda yang menunjukkan kesadaran akan moral, komitmen terhadap hak asasi manusia, kepedulian terhadap lingkungan dan kesadaran akan globalisasi dibandingkan dengan generasi-generasi mereka sebelumnya. Namun, kecenderungannya para generasi muda secara umum lebih menunjukkan gambaran yang lebih kelam.

Menyadari bahayanya dampak kemunduran mental dan tata nilai yang menggerus sendi-sendi kehidupan bangsa Indonesia, pemerintahan baru yang memulai tugasnya pada 20 Oktober 2014 mengumandangkan perlunya melakukan "Revolusi Mental" melalui program Tri Sakti yang pernah diikrarkan oleh Founding Fathers kita. Tri Sakti dijadikan basis dalam pembangunan karakter kebangsaan dan landasan kebijakan nasional, untuk menegakkan kembali kedaulatan, martabat dan kebanggaan sebagai sebuah bangsa, menegaskan kembali fungsi publik negara, menggelorakan harapan di tengah krisis sosial yang mendalam, menemukan jalan bagi masa depan bangsa, dan meneguhkan jiwa gotong-royong. 
Dalam konteks demikian, menjadi kewajiban bagi dunia pendidikan yang merupakan agen pemerintah untuk memainkan peran sebagai institusi yang dengan sadar menjadikan pendidikan karakter sebagai bagian yang tak terpisahkan dalam mencapai tujuan pendidikan nasional. "Anak-anak adalah harta karun negara". Nasib masa depan bangsa ada di pundak anak-anak. Maka, negara yang diwakili oleh lembaga pendidikan perlu memperlakukan anak-anak secara istimewa, baik perkembangan emosional, kesehatan, kecerdasan maupun perilaku mereka. Tidak berlebihan apabila pengelola negara merumuskan dalam lembaran negara dengan rumusan, "Pendidikan nasional berfungsi mengembangkan kemampuan dan membentuk watak serta peradaban bangsa yang bermartabat dalam rangka mencerdaskan kehidupan bangsa, bertujuan untuk berkembangnya potensi peserta didik agar menjadi manusia yang beriman dan bertakwa kepada Tuhan Yang Maha Esa, berakhlak mulia, sehat, berilmu, cakap, kreatif, mandiri, dan menjadi warga negara yang demokratis serta bertanggung jawab" (UUSPN No. 20 Tahun 2003 Bab II Pasal 3). Jadi, pendidikan karakter untuk mencapai tujuan pendidikan nasional dalam konteks menggelorakan revolusi mental adalah mengembangkan kemampuan dan membentuk watak serta peradaban bangsa yang bermartabat dalam rangka mencerdaskan kehidupan bangsa.

Menurut Elkind \& Sweet (2004), Character Education is the deliberate effort to help people understand, care about, and act upon core ethical values. When we think about the kind of character we want for our children, it is clear that we want them to be able to judge what is right, care deeply about what is right, and then do what they believe to be right, even in the face of pressure from without and temptation from within. Karakter merupakan suatu pola perilaku seseorang (Ryan \& Bohlin, 1999: 6). Orang yang berkarakter baik memiliki pemahaman tentang kebaikan, menyukai kebaikan, dan mengerjakan kebaikan tersebut. Orang yang perilakunya sesuai dengan kaidah moral disebut dengan berkarakter mulia. Pendidikan karakter di sekolah bertujuan untuk meningkatkan mutu penyelenggaraan dan hasil pendidikan di sekolah yang mengarah pada pencapaian pembentukan karakter dan akhlak mulia peserta didik secara utuh, terpadu, dan seimbang, sesuai standar kompetensi lulusan. Melalui pendidikan karakter diharapkan para peserta didik mampu secara mandiri meningkatkan dan menggunakan pengetahuannya, mengkaji dan menginternalisasi serta mempersonalisasi nilai-nilai karakter dan akhlak mulia sehingga terwujud dalam perilaku sehari-hari.

\section{Goleman (Siroteak, 2008)} mengemukakan bahwa kesuksesan seseorang tidak ditentukan semata-mata oleh pengetahuan dan kemampuan teknis (hard skill) saja, tetapi juga ditentukan oleh kemampuan mengelola diri dan orang lain (soft skill). Sumbangan hard skill terhadap kesuksesan seseorang hanya sebesar $20 \%$, sedangkan soft skill memberi sumbangan sebesar $80 \%$ atas kesuksesan seseorang. Soft skill merupakan bagian keterampilan seseorang yang lebih bersifat pada kehalusan perasaan seseorang terhadap lingkungannya. Representasi dari soft skill tersebut dilihat pada perilaku santun, keteguhan hati, kemampuan kerja sama, suka menolong orang lain, dan disiplin. Sementara hasil penelitian di Amerika Serikat menyimpulkan besarnya sumbangan kemampuan logika terhadap kesuksesan yang dicapai seseorang hanya sebesar $4 \%$, selebihnya (96 $\%$ ) ditentukan oleh kemampuan otak kanan yang mempunyai andil besar dalam hal kreativitas, imajinasi, inovasi, daya rasa, kreasi seni, kemampuan mencipta dan rekayasa.

Untuk mengimplemetasikan Pendidikan Karakter di kelas, Buchori (2007) menyarankan untuk membawa peserta didik 
ke pengenalan nilai secara kognitif, penghayatan nilai secara afektif, dan akhirnya ke pengamalan nilai secara nyata. Pendidikan karakter diintegrasikan dalam pembelajaran pada setiap mata pelajaran. Materi pembelajaran yang berkaitan dengan norma atau nilai-nilai pada setiap mata pelajaran dikembangkan, dioperasionalkan dan dikaitkan dengan konteks kehidupan sehari-hari. Dengan demikian, pembelajaran nilai-nilai karakter tidak hanya pada tataran kognitif, tetapi menyentuh pada internalisasi, dan pengamalan nyata dalam kehidupan peserta didik sehari-hari di masyarakat. Implementasi pendidikan karakter secara operasional terintegrasi dengan domain kognitif, psikomotor dan sosial dalam pembelajaran matematika inilah yang masih sering menjadi permasalahan bagi guru-guru matematika.

\section{Pendidikan Karakter dalam Pembelajaran Matematika}

Karakter memiliki makna substantif dan proses psikologis yang sangat mendasar. Lickona (1992) merujuk pada konsep good character yang dikemukakan oleh Aristoteles sebagai "...the life of right conduct—right conduct in relation to other persons and in relation to oneself". Karakter dapat dimaknai sebagai kehidupan berperilaku baik/ penuh kebajikan, yakni berperilaku baik terhadap pihak lain (TuhanYangmahaesa, manusia, dan alam semesta) dan terhadap diri sendiri. Karakter yang baik atau good charakter terdiri atas proses psikologis knowing the good, desiring the good, and doing the good-habit of the mind, habit of the heart, and habit of action. Ketiga substansi dan proses psikologis tersebut bermuara pada kehidupan moral dan kematangan moral individu. Dengan kata lain, karakter dimaknai sebagai kualitas pribadi yang baik, dalam arti tahu kebaikan, mau berbuat baik, dan nyata berperilaku baik, yang secara koheren memancar sebagai hasil dari olah pikir, olah hati, oleh raga, dan olah rasa dan karsa.

Terbentuknya karakter anak bangsa yang kuat diyakini merupakan suatu hal yang mutlak dan penting dimiliki oleh setiap peserta didik untuk menghadapi tantangan hidup di masa-masa mendatang. Gerakan pendidikan karakter ini harus merupakan usaha proaktif dan disengaja oleh orang tua, sekolah maupun pemerintah untuk menanamkan dalam diri siswa tentang etika dan nilai-nilai kinerja seperti peduli, kejujuran, ketekunan, kreativitas, inovasi, keadilan, ketabahan, tanggung jawab, dan menghormati diri sendiri dan orang lain. Pendidikan Karakter mengajarkan siswa bagaimana menjadi diri yang terbaik dan melakukan pekerjaan yang terbaik.

Ada tiga langkah yang perlu ditempuh untuk menuju pendidikan nasional yang mempu membangun karakter anak bangsa. Pertama, proses pendidikan, pembelajaran dilaksanakan pada semua jenjang pendidikan dari Pendidikan Usia Dini sampai ke perguruan tinggi (Buchori, 2010). Kedua, pendidikan dan pembelajaran karakter dilaksanakan di sekolah, dalam lingkungan keluarga, maupun di dalam masyarakat. Ketika anak-anak di lingkungan keluarga, orang tua bertanggung jawab memberikan pendidikan karakter. Ketika anak-anak bersosialisasi dengan masyarakat, maka masyarakat tersebut seharusnya memainkan peran dalam pembinaan karakter anak bangsa. Ki Hadjar Dewantara menunjuk sekolah, keluarga dan masyarakat sebagai Tri Pusat Pendidikan yang bertanggung jawab dalam membangun karakter anak bangsa. Ketiga, perlu revolusi proses pembelajaran dari model pembelajaran yang berpusat pada guru (teachers oriented) kepada pembelajaran yang berpusat pada siswa (students oriented), pembelajaran yang memandang siswa sebagai objek pelengkap kepada pembelajaran yang menempatkan siswa sebagai objek yang aktif dalam pembelajaran. Semua proses 
pembelajaran perlu merambah pada aspek kognitif, afektif, psikomotor, dan sosial secara proporsional dengan perencanaan yang matang.

Mampukah pendidikan karakter mengembalikan nilai-nilai masyarakat yang telah tergerus? Kenapa tidak. Keniscayaan itu didasarkan pada keyakinan bahwa pendidikan karakter merupakan investasi nilai-nilai kultural untuk membangun watak, moralitas dan kepribadian masyarakat yang dilakukan berkelanjutan dalam rentang waktu panjang, kontinyu, intens, dan konsisten. Pendidikan karakter membekali kepada peserta didik ilmu, pengetahuan dan pengalaman budaya, perilaku yang berorientai pada nilai-nilai ideal kehidupan, baik yang bersumber pada budaya lokal (kearifan lokal) maupun budaya luar (Tranggono, 2010).

Alwasilah, dkk. (2009: 25-26) mengidentifikasi ada banyak local genius khasanah budaya bangsa Indonesia yang tergali. Lokalitas itu sarat makna dan kaya akan nilai-nilai luhur budaya bangsa. Jika potensi budaya ini menjadi bagian penting dalam pendidikan nasional, maka harapan menjadi bangsa yang 'berjati diri' akan terwujud. Di lain pihak, telah dilakukan diskusi-diskusi tentang gagasan bahwa matematika memiliki sejarah budaya dan perbedaan budaya di antara kelompok masyarakat dapat menghasilkan pengetahuan matematika yang berbeda pula. Bishop et.al (2006) mengasumsikan adanya harmonisasi atau kesesuaian antara matematika sekolah dan budaya yang dibawa siswa dari rumah atau lingkungannya.

Nunes (1992) menyatakan bahwa pengetahuan matematika dapat dipelajari dan dilakukan di luar sekolah oleh berbagai kelompok budaya, dan hal itu memberikan sumbangan yang signifikan untuk menganalisis proses pembelajaran matematika di sekolah. Knijnik (2002 menyarankan agar pemilihan materi matematika, nilai-nilai budaya, dan prinsip-prinsip dipertimbangkan secara bijaksana sebagai bagian dari kurikulum yang dikembangkan oleh sekolah. Salah satu pengaruh yang paling signifikan dari matematika yang digunakan oleh masyarakat (etnomatematika) dalam pendidikan, kata Bishop, et.al (2006), berkaitan dengan nilai-nilai dan kepercayaan, hal itu memberikan kesadaran bahwa setiap kegiatan matematika melibatkan nilai-nilai, keyakinan dan pilihan pribadi. Dari perspektif etnomatematika, Ambrosio (1997) berpendapat bahwa pendidikan matematika telah mencerminkan perubahan yang signifikan, sebagian besar didasarkan pada fakta bahwa matematika tertanam dalam budaya yang beragam, tetapi sering tidak disadari oleh para pengajar di sekolah.

Einstein mengajarkan kepada generasi muda tentang multi-dimensional atas segala-galanya. Ia menyarankan untuk mengembangkan pengetahuan pada dimensidimensi yang lebih tinggi, dan itu berarti bahwa perkara-perkara yang dihadapi oleh generasi berikut semakin tidak sederhana, yang semula vital dan fundamental menjadi kabur, bersifat terbuka dan toleran. Dalam proses pembelajaran perlu dikembangkan pemikiran kreatif yang berbasis pada konsepsi yang telah dimiliki siswa untuk mengembangkan pengetahuannya sendiri, para peserta didik belajar tentang menghargai pendapat orang lain, mengkritisi (mengontrol) pendapat orang, berdemokrasi, berpikir terbuka, bersikap toleran, dan hidup merdeka (Sutrisno, 2002). Bagaimana para peserta didik belajar hidup merdeka ? Dalam pembelajaran dikembangkan kerangka pemikiran alternatif melawan kerangka berpikir benar-salah. Kebenaran diterima sebagai penjelasan terbaik pada masa itu, yang didasarkan pada tingkat kemasukakalan (plausibility) dan kemanfaatan (usefulness). Kebenaran menjadi relatif. Karena para siswa saling memperhatikan konsepsi dan mempertimbangkan argumentasi mereka, mereka menyerap berbagai konsepsi melalui 
sudut pandangnya masing-masing. Mereka akan belajar berpikir alternatif, relativistik, dan berpikir multidimensional. Dalam situasi ini masing-masing siswa dapat hidup merdeka, terbebas dari tekanan.

Sehubungan dengan itu, BSNP (2006) menganjurkan kepada pendidik matematika agar pembelajarannya dilaksanakan dalam suasana yang membuat siswa aktif, merangsang kreativitas, mendorong pemikirian inovatif, menyenangkan bagi siswa, tetapi berlangsung secara efektif dalam pencapaian tujuan, dengan menegakkan sendi-sendi: (a) keimanan dan ketaqwaan kepada Tuhan Yang Maha Esa; (b) belajar memahami dan menghayati lingkungan dan orang lain; (c) belajar untuk berbuat secara efektif; (d) belajar hidup bersama dan memberi manfaat bagi orang lain dan; (e) belajar untuk membangun dan menemukan jati diri. Niat pemerintah lewat BSNP dinilai luhur dan cerdas, namun selama guru, (pimpinan) sekolah, pengembang kurikulum masih berpegang pada kulturnya, apapun kurikulumnya tidak akan berdampak besar (Alwasilah, 2008). Tulisan ini diorientasikan agar dapat menimbulkan konflik kultur dalam pemikiran guru maupun pimpinan sekolah, sehingga mau mengubah pandangannya sesuai dengan kurikulum yang berlaku.

Mc Leod, (1992); Zan, et.al (2006) menekankan peran fundamental domain afektif dalam proses mengajar dan belajar matematika. Mc Leod (1992) membahas eksistensi tiga aspek utama yang berkaitan dengan pengaruh, yang harus dipertimbangkan dalam pendidikan matematika adalah: keyakinan (beliefs), pengembangan pembelajaran matematika dengan melibatkan para siswa; emosi, gangguan provokasi dan hambatan-hambatan belajar, pembimbingan kepada para siswa yang mengalami sentimen positif atau negatif dalam belajar; dan sikap, pengembangan tanggung jawab, kedisiplinan, dan kreativitas dalam diri siswa. De Bellis \& Goldin (Zan, et al, 2006) dalam kegiatan penelitiannya menambahkan elemen keempat tentang pengaruh dari pendidikan matematika, yaitu : nilai-nilai.

Sampai sekarang masih banyak orang berpikiran bahwa belajar matematika lebih banyak bersifat perhitungan saja. Padahal, matematika dapat dianggap sebagai sebuah karya seni. Matematika bukan sekedar kegiatan menghitung, tetapi banyak yang berkaitan dengan pemberdayaan berbagai kekayaan yang terdapat di sekitar kehidupan siswa menjadi sumber pembelajaran (matematika) untuk memahami suatu fenomena. Oleh karena itu, sebagai orang yang bergelut dalam pembelajaran matematika, kita meski berpikir dan mencari karya yang berguna dalam pembelajaran matematika, agar dapat mengajar dan mendidik siswa menuju masa depannya sebagaimana dicita-citakan dalam pendidikan nasional.

Pembelajaran matematika di sekolah tidak hanya hitung-menghitung (Griffith \& Sumantri; 1992), tetapi aktivitas sehari-hari yang dilakukan oleh siswa juga dapat dimaknai secara matematis. Bahkan Freudenthal (1991) menyatakan, "mathematics as a human activity". Matematika pada dasarnya adalah aktivitas yang tidak pernah lepas dari kehidupan sehari-hari, namun demikian diperlukan suatu keinginan, kreativitas, dan inovasi agar terjadi pemikiran-pemikiran yang mengarah pada pembelajaran matematika. Siswa memerlukan pembimbingan dari agar dapat menghubungkan kegiatan yang berbasis pada kekayaan lokal atau pengetahuan yang dimilikinya sehingga mereka belajar matematika secara bermakna.

\section{Membangun Kejujuran melalui Pembelajaran Matematika}

Albert Einstein, seorang ilmuwan Yahudi pernah mengatakan, "ilmu tanpa agama buta, dan agama tanpa ilmu lumpuh". 
Pernyataan tersebut menekankan perlunya keseimbangan atas dua aspek, yaitu pemahaman agama untuk melandasi penguasaan ilmu pengetahuan dan teknologi, dan yang kedua perlunya pengetahuan dan teknologi dalam pengamalan agama. Kita sangat memahami bahwa agama merupakan roh dari akhlak atau moral manusia. Salah satu karakter yang menjadi "rahasia" kesuksesan para CEO dari raksasa perusahaan di tingkat dunia adalah karakter kejujuran. Karakter ini menempati urutan pertama yang harus dimiliki oleh Powerfull Leader dunia, dan tidak tergeser sejak survey tahun 1987. Sementara kemampuan intelegensi, kemampuan logika hanya mendapat tempat pada urutan ke-5.

Kejujuran merupakan pondasi utama atas tegaknya nilai-nilai kebenaran karena jujur itu identik dengan kebenaran. Dalam kitab al-Qur'an dinyatakan: "Wahai orangorang yang beriman! Bertakwalah kamu kepada Allah Swt. dan ucapkanlah perkataan yang benar." (Q.S. al-Ahzāb, 33:70). Perkataan orang beriman harus sesuai dengan perbuatannya karena sangat berdosa bagi orang-orang yang tidak mampu menyesuaikan perkataannya dengan perbuatan, atau berbeda apa yang di lidah dan apa yang diperbuat. Allah Swt. berfirman, "Wahai orang-orang yang beriman! Mengapa kamu mengatakan sesuatu yang tidak kamu kerjakan? (Itu) sangatlah dibenci di sisi Allah jika kamu mengatakan apa-apa yang tidak kamu kerjakan." (Q.S. ash-Shaff; 61:2-3). Pesan moral dari ayat tersebut adalah memerintahkan konsistensi antara perkataan dan perbuatan. Ketidaksesuaian antara yang diucapkan dengan yang diperbuat oleh seseorang merupakan amalan yang dibenci di sisi tuhan dan di mata manusia. Sesungguhnya, perilaku jujur dapat menghantarkan manusia yang melakukannya mencapai kesuksesan.

Kini kejujuran menjadi sebuah kata yang sederhana tapi sekarang menjadi barang langka dan sangat mahal harganya. Ketika orang berada dalam kondisi berkecukupan dan berperasaan senang, mengamalkan kejujuran secara konsisten rasionalnya tidak seberat bagi orang yang banyak mengalami kesulitan. Kejujuran menjadi buah bibir banyak orang, kejujuran hadir secara membahana. Kita seakan baru mengenal kata dan sifat mulia, "jujur". Apakah kita memiliki karakter jujur ini atau sebaliknya? Hal itu dapat ditentukan dengan melihat dari tindakan kita masing-masing ketika berpikiran bahwa tidak ada orang lain yang melihat perilaku kita.

Salah satu teknik untuk menguji kejujuran telah dilakukan survei sederhana dengan cara memancing orang-orang dari berbagai negara dan memberi kesempatan untuk memperlihatkan karakternya ketika mereka berpikir tidak ada orang lain yang melihat. Percobaan kehilangan 1.100 dompet (Lickona, 2004) digunakan untuk mengetahui banyaknya dompet yang dikembalikan. Setiap dompet berisi uang senilai $\$ 50$ dalam mata uang masing-masing negara, kartu identitas dan nomor telepon pemilik dompet. Dompet "ditinggal" diberbagai lokasi, seperti: pinggir jalan, warnet, depan gedung, mall, geraja, serta di tempat parker dan restoran. Hasil percobaan menyebutkan, $56 \%$ sasaran mengembalikan dompet, dan sisanya $44 \%$ membawa pergi dompet tersebut. Karakter kejujuran dijunjung tinggi oleh masyarakat Norwegia dan Denmark, mereka mengembalikan $100 \%$ dompet yang disebarkan di negaranya. Sedangkan empat negara yang dikategorikan berkarakter kejujuran rendah adalah Italia (35\% mengembalikan), Swiss (35\%), Hongkong $30 \%$ dan Meksiko $21 \%$. Indonesia?

Pada pertengahan 2013, majalah Reader's Digest juga melakukan tes tentang kejujuran (http://archive.indianexpress.com). The magazine put 16 cities to the test when wallets were dropped in public. Of the 192 wallets, around half were returned, but the outcomes varied from city to city. The result: 
Helsinki is the winner. The capital of Finland emerged as the most honest city of the world with eleven out of 12 wallets being returned to their owners in the Scandinavian city. Lasse Luomakoski, a 27-year-old businessman, found the magazine's wallet downtown. "Finns are naturally honest," he said. "We are a small, quiet, closely-knit community. We have little corruption, and we don't even run red lights," he told Reader's Digest. India's financial capital Mumbai was the second most honest city in the world with nine out of 12 wallets getting handed in. Vaishali Mhaskar, a mother of two, returned a wallet left in the post office. "I teach my children to be honest, just like my parents taught me," she said. Portugal capital Lisbon was the most dishonest with only one wallet being returned to its owner.

Apa nilai moral dari survey tersebut? Jawabannya adalah masalah budaya. Karakter dari komunitas atau Negara - dalam hal ini norma kejujuran - mempengaruhi karakter warganya. Tetapi, tidak menentukan karakter mereka, karena dari tempat yang paling tidak jujur - beberapa orang masih mengembalikan dompet yang ditemukannya. Hal itu memberi harapan, jika kita dapat meningkatkan normanorma kelompok (sekolah, lingkungan, atau komunitas), masih mempunyai kesempatan meningkatkan karakter pada kelompok yang bersangkutan. Apa dasarnya? Sebagian besar orang yang mengembalikan dompet, tua dan muda, mengemukakan bahwa orang tua mereka menanamkan ajaran untuk melakukan hal yang benar dalam diri mereka, "jangan menginginkan barang milik sesamamu". Sebagian yang lain menyatakan keyakinan agama menjadi alasan untuk kejujuran yang mereka pegang.

Aktivitas survei di atas menginspirasi untuk membelajarkan kejujuran melalui masalah-masalah dalam pembelajaran matematika. Masalah itu tentu saja berkaitan dengan menemukan dompet jatuh.
1. Beberapa hari ini ada dua perkara yang mengganggu pikiran Andi.

2. Retsleiting tas-nya rusak. Menurut pengalaman, kalau retsleiting sudah mulai macet-macet, biasanya dalam 2-3 hari pasti benar-benar rusak. Itu berarti ia harus membeli tas baru dan memerlukan uang sejumlah Rp. 200.000-an.

3. Sementara ia juga ada janji hendak menengok Ilva yang tengah terbaring di rumah sakit, sedangkan ongkosnya dengan kendaraan ekonomi Rp. 50.000-an sekali jalan.

4. Persis hari ini retsleting tas Andi benarbenar rusak. Ia berpikir dan memutuskan untuk membeli tas kresek sebagai pengganti daruratnya. Karena itu ia mencari-cari toko. Nah, di saat itulah Andi menemukan uang 3 lembar Rp. 100.000an. Hah?! Cukup itu! "Dua perkara itu terjawab sudah", gumam Andi.

5. Bagaimana menurut anda? Setuju dengan Andi?

\section{Pengembangan Kreativitas dan Inovasi dalam Pembelajaran Matematika}

Pengembangan kreativitas dalam pembelajaran masih belum banyak orang yang melakukannya (Mahmudi, 2008). Kreativitas merupakan suatu kondisi, suatu sikap, keadaan mental yang sangat khusus sifatnya. Kreativitas bukan hanya muncul dari suatu hasil pemikiran dan dorongan perasaan, namun juga melibatkan kepekaan intuitif (Retnowati, 2009). Kreativitas sering diasosiasikan dengan suatu produk kreatif, tetapi kreativitas juga dapat ditinjau dari prosesnya (Dickhut, 2007). Proses mneghasilkan suatu produk kreatif, selalu diawali dengan konstruksi ide kreatif. Ide kreatif ini diperoleh dari proses berpikir yang melibatkan aktivitas kognitif. Proses demikian disebut sebagai proses berpikir kreatif (Mc Gregor, 2007). Proses kreatif merujuk pada usaha individu 
untuk menghasilkan solusi atau produk kreatif.

Menurut Pehnoken (1997), kreativitas tidak hanya ditemukan dalam bidang tertentu, seperti pada seni dan sains saja, tetapi juga merupakan bagian dari kehidupan sehari-hari. Kreativitas ditemukan juga dalam matematika. Bishop (Pehnoken, 1997) mengemukakan bahwa seseorang memerlukan dua keterampilan dalam berpikir matematis, yaitu berpikir kreatif, yang sering diidentikkan dengan intuisi, dan kemampuan berpikir analitik, yang diidentikkan dengan kemampuan logis. Padahal sesuatu yang intuitif itu bersifat bawah sadar, berada dalam wilayah otak kanan.

Pada tulisan Retnowati (2009) dikemukakan bahwa proses berpikir bawah sadar, memasuki wilayah proses perubahan, pertumbuhan, proses evolusi, proses perenungan, dan proses mencipta dalam organisasi pada kehidupan subjektif pikiran manusia. Chapman mengemukakan ada tiga tahap untuk melakukan proses kreatif yaitu: (1) Inception of an idea, merupakan tahap menemukan gagasan, mencari sumber gagasan, inspirasi, (2) Elaboration and refinement, yaitu proses pengembangan, pemantapan dan penyempurnaan gagasan menjadi suatu gambaran pravisual sebagai cetak biru dari wujud yang konkrit, (3) Execution in a medium, merupakan tahap terakhir sebagai proses visualisasi gagasan menjadi suatu karya seni (Retnowati, 2009).

Berdasarkan uraian di atas dapat dikemukakan bahwa proses kreatif merupakan pengejawantahan emosi dan representasi dari pemikiran pembuat karya sekaligus merupakan proses aktualisasi diri atau kapabilitas dalam mewujudkan karya seni. Retnowati, (2009) mengemukakan bahwa unsur pendorong dalam laku kreatif meliputi sarana, keterampilan, orisinalitas karya, apresiasi, lingkungan, dan identitas. Hal senada dikemukakan oleh Munandar (1999: 50) dengan mengatakan bahwa kreativitas merupakan kemampuan yang mencerminkan kelancaran, keluwesan (fleksibilitas) dan orisinalitas berpikir, serta kemampuan mengelaborasi (mengembangkan, memperkaya, memperinci) suatu gagasan. Tampilan karya yang kreatif selalu tampil tunggal (unicness), karena tidak terdapat kembarannya; asli (original), karena dihasilkan oleh diri sendiri pelaku seni, dan bersifat baru (novelty) sebelumnya belum pernah ada.

Pengembangan karakter kreatif dan inovatif perlu dilakukan sejak dini kepada peserta didik, ketika mereka masih duduk di bangku sekolah dasar. Pentingnya mengembangkan kemampuan kreativitas dan inovasi bagi peserta didik agar kelak mereka mempunyai kemampuan berinteraksi dalam masyarakat, kemampuan bersaing yang dilandasi etika, moral, dan kesantunan. Dalam kehidupan dunia industri dan dunia usaha terjadi persaingan pasar demikian ketatnya. Hampir setiap hari dikenalkan produk-produk baru sebagai karya kreatif dan inovasi baru. Bila ingin sukses, para pelaku usaha harus berusaha menjadikan dirinya sebagai orang yang kreatif dan inovatif, ketiadaan kreativitas dan inovasi dalam dunia industri dan usaha hanya akan membuat usahanya tergerus oleh persaingan pasar. Penciptaan produk-produk baru yang berbeda dari produk lainnya dapat memberikan nilai lebih dibandingkan dengan produk lainnya. Hal itu menunjukkan bahwa kemampuan kreativitas dan inovasi dapat menjadi faktor penting yang menopang kesuksesan seseorang. Itu merupakan satu di antara sekian banyak alasan untuk mengembangkan kemampuan kreativitas dan berinovasi bagi peserta didik sejak dini.

Inti dari inovasi adalah mengubah sesuatu yang biasa menjadi luar biasa. Mengubah sesuatu yang tadinya tidak atau kurang bernilai menjadi lebih bernila. Jadi sebuah karya disebut inovatif bila ada nilai tambah yang dihasilkan dari karya tersebut. Nilai tambah tersebut bisa berupa peningkatan kualitas, peningkatan layanan, dan pening- 
katan efisiensi. Sebuah karya inovatif dikategorikan baik, apabila memenuhi (bagian) prinsip-prinsip berikut: 1) Original dan belum pernah dibuat oleh orang lain. 2) Relevan, mempunyai manfaat bagi penggunanya. 3) Menarik, menjadi kebutuhan bagi penggunanya. 4) User Friendly (praktis) dan mudah digunakan. 5) Efisien, mampu mereduksi biaya sehingga menghasilkan karya dengan biaya lebih murah. 6) Kompetitif, berbiaya lebih murah, tetapi fungsinya lebih baik, dan desainnya lebih menarik. 7) Up to date, sesuai dengan trend yang berkembang. 8) Available, bahan baku tersedia di sekitarnya, teknologinya tidak terlalu rumit dan dapat diproduksi secara massal. 9) Sustainable, memiliki fungsi jangka panjang. Bukan kegunaan sesaat, dapat dikembangkan varian berikutnya sesuai perkembangan jaman. 10). Ramah lingkungan, menggunakan bahan-bahan yang ramah lingkungan dan mampu didaur ulang.

Saat ini masih sangat sulit untuk mempertahankan kejeniusan seorang anak karena, seiring ia bertambah dewasa, kreativitasnya justru dihambat dan dimatikan. Sir Ken Robinson, pakar pendidikan dunia mengatakan, "Kita tidak tumbuh menjadi kreatif. Kita justru tumbuh menjadi tidak kreatif, atau lebih tepatnya, kita dididik keluar dari kreativitas." Dalam buku "Breakpoint and Beyond" diungkapkan sebuah penelitian yang menguji kreativitas anak. Sekelompok anak usia 3-5 tahun diuji, lalu 5 tahun kemudian saat berusia 8-10 tahun mereka diuji kembali, dan terakhir diuji sekali lagi saat mereka berusia 13-15 tahun. Sekelompok orang dewasa berusia di atas 25 tahun juga diuji sebagai kelompok kendali. Hasilnya adalah sekolah berhasil memadamkan kejeniusan anak-anak seiring bertambahnya usia.

Bagaimana cara mengembangkan kreativitas para siswa hingga dewasa? Dalam pembelajaran matematika berbasis kekayaan lokal (budaya) masyarakat ditekankan pada aktivitas apresiasi (appreciation) dan kreasi (creation), serta keterampilan berkarya. Aktivitas apresiasi bertujuan untuk mengembangkan kesadaran, pemahaman, dan penghargaan terhadap karya seni, yang dilakukan dengan pengamatan dan memberi respon hasil karya yang mempunyai muatan estetik. Kegiatan pengamatan bertujuan untuk memperoleh pengalaman estetik, melalui pencerapan nilai intrinsik dari suatu karya seni. Untuk mengukur respon estetik terhadap suatu karya dapat dilakukan dengan menggunakan instrumen afektif. Salah satu jenis instrumen untuk mengukur pemaknaan siswa terhadap karya seni adalah semantic differential yang dikembangkan oleh Osgood, Suci, dan Tannenbaum (Prihadi, tanpa tahun). Pada kegiatan kreasi (creation), siswa diakomodasi untuk mengekspresikan pengalaman estetiknya dalam wujud karya siswa yang bermuatan estetik. Produk karya siswa tersebut merupakan keterampilan berkarya. Aktivitas yang dilakukan melalui kegitan eksplorasi dan eksperimen mengolah gagasan (konsep), bentuk, media (teknik), dengan menggunakan unsur-unsur titik, garis, warna, bidang, tekstur, volume, dan ruang untuk mewujudkan karya seni, baik tradisi maupun modern, secara individual maupun kelompok.

Teknis detailnya sangat tergantung pada banyak faktor, namun ada beberapa prinsip universal yang layak untuk dijalankan. Anak lebih banyak diberi kesempatan dan dorongan, bukan feedback negatif. Berikan pujian atas keberaniannya untuk melakukan percobaan, bukan hanya pada hasil akhir. Cintai mereka tanpa syarat. Saat berpetualang dan mencoba hal-hal baru, anak memerlukan kepastian bahwa orang tuanya tidak akan berhenti mencintainya apapun hasil yang diraih. Hargai keunikan tiap anak. Dorong untuk lebih mengeksploitasi kekuatannya, bukan menutupi kelemahannya. Berikan kesempatan yang cukup tetapi tuntut tanggung jawabnya untuk menjelajah dunia dengan imajinasinya. 


\section{Matematika dan Keimanan}

Sebagian petikan tanya jawab antara Tom (santri dari satu pondok) kepada Sang Kyai Nasrudin terekam seperti transkrip berikut.

Sang Kyai : Sudah Tom, cukup-cukup...., Sebagai penutup, apa kamu ada pertanyaan?

Tom : Iya nih Pak kyai..., di sekolah itu kan saya belajar matematika. Terus, kata pak guru saya, matematika itu erat dengan kehidupan. Terkait dengan hampir semua aktivitas kita sebagai manusia. Bisa menjelaskan fenomena alam, pun juga bisa menambah yakin dan imannya kita terhadap ke-Mahabesaran Allah SWT. Nah, saya masih belum mengerti, apa kaitannya matematika dan keimanan seseorang itu pak kyai? Apakah makin pandai matematika itu bikin kita makin beriman atau bagaimana? Padahal banyak yang pandai matematika, malah tak beriman, tak mengakui adanya Tuhan..."

Dalam naskah Creative Thinking: An Islamic Perpective (Badi \& Tajdin, 2004) dikemukakan bahwa matematika di lingkungan Islam meliputi berbagai disiplin, antara lain ilmu bilangan, aljabar, geometri, astronomi, dan musik. Kontribusi kaum muslim yang mendapat pujian yang luar biasa adalah penemuan bilangan nol atau sifr. Penemuan itu memberi kemudahan untuk menerapkan aritmetika dalam rangka memecahkan persoalan-persoalan sehari-hari yang berkaitan dengan perdagangan, pembagian tanah dan hak waris. Matematika telah digunakan oleh cendekiawan muslim untuk mengkaji dan memahami fenomena fisik disamping demi aktivitas sehari-hari yang memerlukan perhitungan. Karya matematika yang fenomenal dilakukan oleh Al Khawarizmi yang menulis Hizab Al-Jabr wa Al-Muqabalah (Aljabar) dan Algoritmi de numero Indorum (Algoritma). Al Biruni menyumbangkan Tahdid (Batas Pemisah Koordinat Kota) ditulis untuk menentukan kiblat. Ia juga telah membahas rotasi bumi pada porosnya, mengkalkulasi keliling bumi, serta menghasilkan karya lebih dari 146 judul yang meliputi astronomi, matematika, geometri, mekanika, farmasi, mineralogy, sejarah, sastra, agama dan filsafat.

Kontribusi ilmuwan muslim pada bidang astronomi sangat kental. Praktek ajaran Islam memerlukan pengetahuan tentang astronomi. Peredaran bulan dan matahari sangat penting bagi kehidupan kaum muslim sehari-hari. Bulan diperlukan untuk menentukan waktu puasa, astronomi untuk menentukan arah kiblat ketika sholat. Sangat wajar bila rujukan Al Quran tentang langit, bulan dan matahari dipandang sebagai ilham bagi kaum muslim untuk mempelajari astronomi. Di bidang fisika, dikenal Quthb Al-Din Al Syirazi sebagai ahli optic, dan Al Khazani dan Al Baghdadi membahas tentang pengukuran berat jenis dan gravitasi, dan membuktikan bahwa kecepatan benda jatuh bebas tidak bergantung pada massanya, dengan syarat tidak ada gaya eksternal yang menentang atau bersifat friksional.

Penemuan pengetahuan pada berbagai disiplin yang bersumber pada Al Quran oleh ilmuwan muslim tersebut menginspirasi kita untuk menyelidiki aturan alam dan perangkatperangkat umum dari materi seperti yang ditimbulkan oleh energy (fisika), atau mempelajari struktur dan unsur-unsur mineral dari bumi (kimia). Al Quran juga mendorong untuk mempelajari tentang bumi (geologi), bentuk fisiknya berupa laut, daratan, gunung, sungai (geografi), struktur dan fungsi organis manusia, fungsi klasifikasi tumbuh-tumbuhan dan binatang (biologi); serta gerakan-gerakan angin pembentrukan evolusi awan dan turunnya hujan (meteorology). Dalam 
kesempatan ini Al Quran digunakan sebagai rujukan untuk memperkuat keyakinan dan menambah keimanan para peserta didik melalui pembelajaran matematika.

Dalam surat Al Muddatstsir (QS, 74: 30) didapati satu ayat pendek yang artinya, "Di atasnya ada Sembilan belas". Para penafsir terdahulu telah membuat perkiraan dengan dugaan-dugaan yang indah mengenai makna "19". Pada ayat berikutnya dikemukakan: " ... dan tidaklah Kami menjadikan bilangan mereka itu melainkan untuk jadi cobaan bagi orang-orang kafir, supaya orang-orang yang diberi Al-Kitab menjadi yakin dan supaya orang yang beriman bertambah imannya dan supaya orang-orang yang diberi Al-Kitab dan orangorang mu'min itu tidak ragu-ragu ... ". Dalam berbagai aktivitas kehidupan sehari-hari, bilangan selalu dijadikan rujukan untuk meyakinkan orang lain, atau untuk menyombongkan diri (cobaan). Untuk mengetahui tingkat keberhasilan (kekayaan, prestasi, kecepatan, dsb) seseorang menggunakan bilangan untuk melihat perbandingannya. Demikian pula dalam penciptaan manusia, Allah, swt juga melibatkan unsur bilangan 19. Hal itu dapat diperiksa pada jumlah ruas jari pada telapak tangan kita masing-masing terdiri dari 19 ruas. Keduanya berfungsi seimbang, berkerjasama dengan baik untuk kepentingan pemiliknya, dapat digerakkan sedemikian sehingga secara bersama-sama sangat berperan dalam melakukan berbagai aktivitas. Firman Allah, swt: "Kami akan memperlihatkan kepada mereka tanda-tanda Kami di segala wilayah bumi dan pada diri mereka sendiri, hingga jelas bagi mereka bahwa Al-Quran itu adalah benar. Tidak cukupkah bahwa sesungguhnya Tuhanmu menjadi saksi atas segala sesuatu?" ( QS. Fushilat, 41:53).

Albert Einstein, tokoh utama yang memimpin revolusi di dunia fisika mengemukakan bahwa, "kecepatan cahaya merupakan tetapan alam yang besarannya bersifat absolut dan tidak bergantung kepada kecepatan sumber cahaya dan kecepatan pengamat". Menurut Einstein, tidak ada yang mutlak di dunia ini kecuali kecepatan cahaya, dan ia merupakan kecepatan tertinggi di alam ini. Artinya, tidak mungkin ada (materi) yang kecepatannya melebihi kecepatan cahaya. Sifat unik cahaya yang menurut Einstein adalah satu-satunya komponen alam yang tidak pernah berubah, membuat sebagian ilmuwan terobsesi untuk menghitung sendiri besaran kecepatan cahaya dari berbagai informasi. Bagaimana caranya?

Seorang ilmuwan matematika dan fisika dari Mesir, Dr. Mansour Hassab Elnaby (Elnaby, 1990) tertarik untuk menghitung kecepatan cahaya. Elnaby menguraikan cara menghitung kecepatan cahaya berdasarkan redaksi ayat-ayat Alquran. Dalam menghitung gerakan benda langit, ia menggunakan sistem yang umumnya dipakai oleh ahli astronomi yaitu sistem Siderial. Sistem ini didasarkan pada gerakan relatif Bulan dan Matahari dilihat dari bintang jauh (pusat semesta). Sistem ini menjadi dasar perhitungan kalender Islam (Hijriah) di mana satu bulan = 27,321661 hari . Beberapa ayat Alquran yang menjadi rujukan Dr. Elnaby, antara lain:

1. (QS, Yunus, 10:5) "Dialah (Allah) yang menciptakan Matahari bersinar dan Bulan bercahaya dan ditetapkannya tempat bagi perjalanan Bulan itu, agar kamu mengetahui bilangan tahun dan perhitungan ".

2. (Q.S. Al Anbia, 21:33) "Dialah (Allah) yang menciptakan malam dan siang, matahari dan bulan masing-masing beredar dalam garis edarnya".

3. (Q.S. As-Sajdah, 32:5) "Dia mengatur urusan dari langit ke Bumi, kemudian (urusan) itu kembali kepada-Nya dalam satu hari yang kadarnya seribu tahun menurut perhitunganmu".

Dari ayat-ayat di atas dapat diambil kesimpulan bahwa jarak yang dicapai "sang 
urusan" selama satu hari adalah sama dengan jarak yang ditempuh Bulan selama 1.000 tahun atau 12.000 bulan. Dr. Elnaby menyatakan bahwa "sang urusan" inilah yang diduga sebagai sesuatu "yang berkecepatan cahaya".

Dengan menggunakan rumus sederhana tentang kecepatan, didapatkan persamaan:

$$
\mathrm{C} \times \mathrm{t}=12.000 \times \mathrm{L}
$$

dengan: $\mathrm{C}=$ kecepatan "sang urusan" atau kecepatan cahaya

$\mathrm{t}=$ kala rotasi Bumi $=24 \times 3600$ detik $=$ 86164,0906 detik

$\mathrm{L}=$ jarak yang ditempuh Bulan dalam satu edar $=\mathrm{V}$ x T

Untuk menghitung L, perlu menghitung kecepatan Bulan. Jika kecepatan Bulan dinotasikan dengan $\mathrm{V}$, maka diperoleh persamaan:

$$
\mathrm{V}=(2 \times \text { phi } \times \mathrm{R}) / \mathrm{T}
$$

$\mathrm{R}=$ jari-jari lintasan Bulan terhadap Bumi $=$ $324264 \mathrm{~km}$

$\mathrm{T}=$ kala Revolusi Bulan $=655,71986$ jam, sehingga diperoleh

$\mathrm{V}=3682,07 \mathrm{~km} /$ jam (sama dengan hasil yang diperoleh NASA)

Diperoleh C $=12.000 \times 2152612,336257 \mathrm{~km}$ / 86164,0906 detik $=299.792,4998$ km/dtk

Banyak ayat-ayat Al-Qur'an yang secara langsung maupun tidak langsung mengungkapkan fenomena-fenomena alam yang dapat dijelaskan secara logika. Manusia harus menggunakan kemampuan yang dikaruniakan oleh Allah, swt untuk memahami dan memanfaatkannya untuk kebaikan bagi kehidupan manusia. Dalam pandangan Islam kegiatan ilmiah yang bernilai ibadah ditandai dengan:

1. sejalan dengan isi dan kandungan AlQur'an

2. harus membawa manfaat bagi umat manusia

3. membawa pengakuan terhadap kemahakuasaan Allah
4. membawa kedekatan kepada Sang Khaliknya

\section{Kesimpulan}

Beberapa hal yang dapat disimpulkan dari uraian pada artikel ini adalah:

1. Terbentuknya karakter anak bangsa yang kuat diyakini merupakan suatu hal yang mutlak dan penting dimiliki oleh setiap peserta didik untuk menghadapi tantangan hidup di masa-masa mendatang.

2. Materi pembelajaran yang berkaitan dengan norma atau nilai-nilai pada setiap mata pelajaran dikembangkan, dioperasionalkan, dan dikaitkan dengan konteks kehidupan sehari-hari.

3. Dalam proses pembelajaran perlu dikembangkan pemikiran kreatif yang berbasis pada konsepsi yang telah dimiliki siswa untuk mengembangkan pengetahuan-nya sendiri, para peserta didik belajar tentang menghargai pendapat orang lain, mengkritisi (mengontrol) pendapat orang, berdemokrasi, berpikir terbuka, bersikap toleran, dan hidup merdeka.

4. Matematika pada dasarnya adalah aktivitas yang tidak pernah lepas dari kehidupan sehari-hari, namun demikian diperlukan suatu keinginan, kreativitas, dan inovasi agar terjadi pemikiranpemikiran yang mengarah pada pembelajaran matematika. Siswa memerlukan pembimbingan dari agar dapat menghubungkan kegiatan yang berbasis pada kekayaan lokal atau pengetahuan yang dimilikinya sehingga mereka belajar mate-matika secara bermakna.

5. Mengembangkan kreativitas siswa dalam pembelajaran matematika berbasis kekayaan lokal (budaya) masyarakat ditekankan pada aktivitas apresiasi (appreciation) dan kreasi (creation), serta 
keterampilan berkarya dengan tujuan mengembangkan kesadaran, pemahaman, dan penghargaan terhadap karya seni, yang mempunyai muatan estetik.

\section{Daftar Pustaka}

Alwasilah, A. Chaedar. 2008. Filsafat Bahasa dan Pendidikan. Bandung: Remaja Rosdakarya.

Alwasilah, A. Chaedar. dkk. 2009. Etnopedagogi: Landasan Praktek Pendidikan dan Pendidikan Guru. Bandung: Kiblat Buku Utama.

Bishop, A.J. 1988. Mathematics Enculturation : a Cultural Perspective on Mathematics Education. Dordrect : Kluwer.

Bishop, A.J. 1994. Cultural Conflicts in Mathematics Education : Developing a Research Agenda. For the Learning of Mathematics. Vol. 14. No. 2

Bishop, A. J. 1996. How should mathematics teaching in modern societies relate to cultural values. Some preliminary questions. In D. T. Nguyen, T. L. Pham, C. Comiti, D. R. Green,

Buchori. M. 2007. Character building dan pendidikan kita, dari http://www. kompas.co.id/kompas-cetak/0607/26/ opini/2836169.htm. diunduh 27 November 2014.

Elnaby, MH, 1990, A New Astronomical Quranic Method for The Determination of The Greatest Speed C, http://www. islamicity.org/Science/960703A

Harris, D. dan Bell, Ch. 1994. Evaluating and Assessing for Learning. New Jersey: Nichols Publishing Company.

Howard, K. 1995. 100 ways to enhance values and morality in schools dan youth settings. Massachusetts: Allys \& Bacon.

Kemdiknas. 2010. Panduan Pendidikan Karakter.(Jakarta: Direktorat Pembinaan SMP).

Kevin, R. and Karen, B. 1999. Building character in schools. San Fransisco: John Willey \& Sons.
Lickona, T. 2004. Character matters: How to help our children develop good judgment, integrity, and other essential virtues. New York:

Mahmudi, A. 2008. Tinjauan Kreativitas dalam Pembelajaran Matematika. Jurnal Pythagoras Jurusan Pendidikan Matematika FMIPA UNY Vol. 4, Nomor 2, Desember 2008, ISSN 1978-4538.

Marfu. K. 2010. Penilaian Pendidikan Karakter, dari http://www.inilahguru. com/index.php?option=com_content\&v $\underline{\text { iew }=\text { article\&id=221. Diunduh tgl } 14}$ Maret 2011

Mechem, R. 2011. The eleven principles of Effective Character Education. Rockwood USA: National School of Character.

NCTM. (1998). Priciples and Standarts for School Mathematics. Reston, VA : National Council of Teachers of Mathematics.

Nunes, T., et.al. 1993. Mathematics in the Streets and in Schools. Cambridge, U.K: Cambridge University Press.

Pehnoken, E. 1997. The State-of-Art in Mathematical Creativity. [Online] Zentralblatt für Didaktik der Mathematik (ZDM) - The International Journal on Mathematics Education. Tersedia: http://www.emis.de/journals/ZDM/zdm 973a1.pdf . [15 Januari 2008]

Permendiknas No. 23 Tahun 2006 tentang Standar Kompetensi Lulusan.

Pinxten, R. 1994. Ethnomathematics and Its Practice. For the Learning of Mathematics Vol. 14 No. 2.

Rao, M.S. 2010. Which are the Employability Skills - Hard Skills or Soft Skills? http://www.career-journal.com/en/ leadership/206.html?infoView=25455. Diunduh 31 Maret 2010

Readers Digest. 2013. Mumbai world's 2nd most honest city in Reader's Digest 'Lost Wallet' survey. http://archive.indian express.com. 
Retnowati, T.H. 2009. Pengembangan Instrumen Penilaian Seni Lukis Anak di Sekolah Dasar. Disertasi. Yogyakarta: PPs UNY.

Sirotiak, T.L 2008. The Effect of problem/ project based learning on a desire skill set. Graduate Theses and Disertation. Iowa State University.

Sutrisno, M. 1993. Estetika: Filsafat Keindahan. Yogyakarta: Kanisius.

Suyanto. 2009. Urgensi Pendidikan karakter. http://enewsletterdisdik.wordpress.com.

Tim Syaamil al Qur'an. 2010. Al Qur'anulkarim, Miracle The Reference. Bandung: Sygma. 